\title{
8 摩擦面の可視化
}

東北大学大場光太郎。, 菅野誠一郎, 足立幸志, 猪岡光, 加藤康司

\section{The Visualization of Friction}

\author{
Kohtaro OHBA*, Seiichiro KANNO*, Koshi ADACHI*, Hikaru INOOKA* and Koji KATO*
}

\begin{abstract}
Considering about the condition of two contactingbodies under tangential force, local and micro slip (tangential displacement) initiates and develops before the macroscopic slip occurs. In this phenomenon, there would be various complicated contact conditions which can not be analyzed theoretically before. In some fields to control the tangential displacement, it is important problem to clarify the mechanism.

In this paper, in order to clarify the mechanism of the tangential displacement, we try to make the micro-slip at the contact interface between rubber and glassplate visualize using the correlation methods.
\end{abstract}

\section{1. まえがき}

一般に, 接触している二つの物体間の相対移動は、一方の物体にある臨界值以上の接線力 が作用したときに発生する。これが巨視的なすべり現象であり,この臨界接線力は, 二物体 間の押し付け力と摩摖係数の積という形で表される.

しかし,巨視的すべりに至る以前，すなわち臨界值以下の接線力が作用した場合において も物体の移動（接線力方向変位の発生）が実験的に明らかにされている[1].

この接線力方向変位の制御は, 工業技術の発展, 高度化にともなう製品に要求される高精 度化,及び特にクリーンルームでは大きな問題となっている機械の微少な振動にともなう微 少な摩耗(フレッチング摩耗)に対し、その鍵を握る重要なテクノロジーであり, 発生機構の 解明が重要な問題となっている.

これに対し, 接線力方向変位の発生する機構として, 過去に大きく分けて二つの理論解析 が行われている.一つは弾性論に基づくR.D.Mindlinによる Annular slip 説 [2]であり, うう一つは 塑性論に基つく D.TaborらによるJunction grouth説である[3]. しかし，実際の二物体間の接触を 考えた場合, 表面の粗さや污れの存在, 更に接触形態に起因する複雑な接触王力分布の存在 等の為, 理論では説明することのできない複雑な接触状態が種々存在する.

そこで、実際の理論では解けないような種々の条件下での二物体間の接触における接線力 方向変位の発生機構解明のための第一歩として, 接触面内微小すべりの可視化の技術を確立 し、これにより接触面内微小すべりの分布状態を明らかにする事は有効であると考えられる。 本研究においては, 接触面に発生する微小すべりの可視化に画像処理技術 [4] 応用する ことを試みる。

\footnotetext{
* Department of Mechanical Engneering, Tohoku University.

Aramaki aza Aoba, Aoba-ku, Sendai, Miyagi, 980, Japan
} 


\section{2. 実験装置及び実験方法}

Fig.1 に, 接触面の直接観察と接触面に発生する微小すべり分布の可視化のための実験装 置の全体図を示す.すべり出し試験機では,ガラス試験片に押し付けられたゴム試験片に接 線力を与え, この時発生する接線力方向変位を測定する。また，ガラス試験片とゴム試験片 の接触面をガラス試験片ホルダーに設けられた観察空を通して直接観察，及びVTR撮影する ことができる。

垂直荷重は,ゴム試験片ホルダー内に設け られたロードセルを用いて所定の垂直荷重 $(24.3 N)$ に設定した後に,ガイドシャフトに取 り付けられたストッパーにより, 平板試験片ホ ルダーの上下方向の变位を拘束してから実

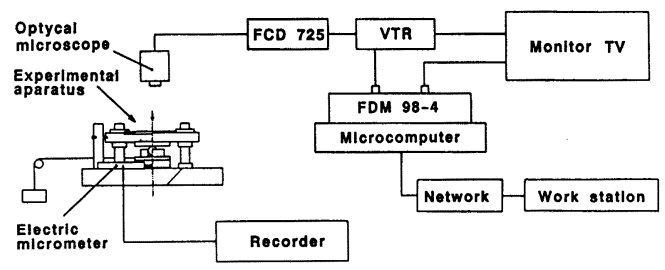
験を行った。接線力は, タンクに水を流し込 むことで与えた。この時接線力の与え方は，

Fig.1: Measurment system. $0.49 \mathrm{~N}$ 毎に $0.020 \mathrm{~N} / \mathrm{S}$ の接線力付加速度で段階的に与えた。

実験中, 接線力方向変位(ゴム試験片ホルダーの変 位)はレコーダーに記録される。また，各接線力で接 線力方向変位が安定したときの接触面を, 光学顕微 鏡を通してVTR撮影が行われた。この様にして得られ た画像は,フレームメモリーボード(FDM98-4)により

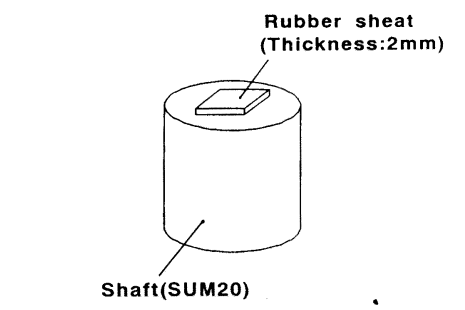
電気信号に変換されてマイクロコンピュータに読み込 まれ，情報をネットワークを介してワークステーショ ンに送り画像処理することにより接触面に発生した 微小すべりを可視化する.

Fig. 2 に, 本実験に用いたゴム試験片の形状を示す. ゴム試験片は, 厚さ $2 m m$ のゴムシートを適当な寸法 に切断したものをSUM20のシャフトの端面に接着した ものを用いた。また，ゴム試験片の表面には，接触面 に発生する微小すべりを追跡するためのトレーサー

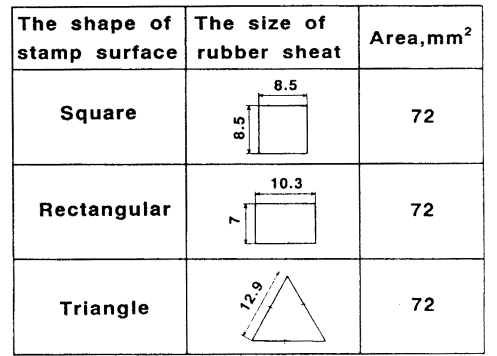

Fig.2: Slip elements. として、スプレー式の油性塗料を散布してある。このトレーサーが, 接線力方向変位と接線 力係数の関係に及ぼす影響はほとんどないことは確認済みである。

\section{3. 接触面内微小すべり分布の可視化手法}

本研究においては, 流れの可視化に代表される動画像の計測の手法として,アルゴリズム が単純で比較的汎用性の高いといわれている以下の相関法 $[5,6]$ を用いる.

ここでは, 接線力が $0 N$ の映像と各接線力の場合の映像を此較する。すなわち, 初期面から の接触面内微小すべり分布図が得られる.また, 得られる接触面内微小すべり分布図は、ガ ラス平板試験片上をゴム試験片が移動した量を示している。 
(a)

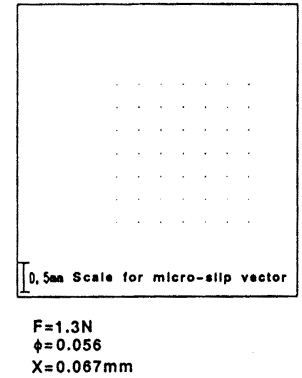

(d)

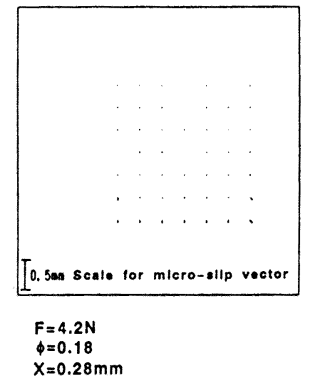

F: Tangentlal force (b)

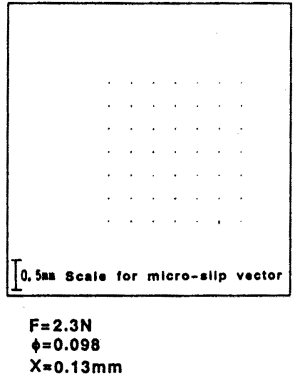

(e)

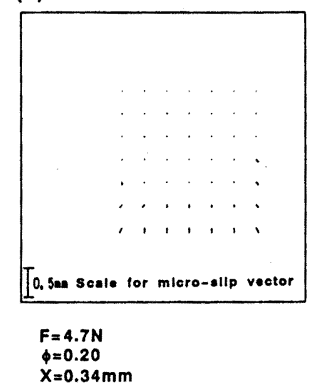

(c)

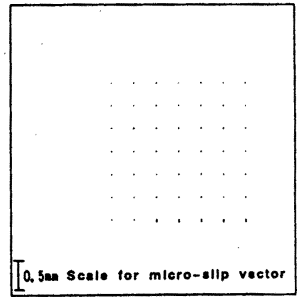

$F=3.2 \mathrm{~N}$
$\phi=0.14$
$X=0.20$

$X=0.20 \mathrm{~mm}$

(f)

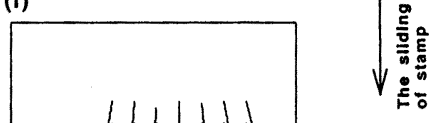

Fig.3: An example of the slip surface visualization.

\section{4. 実験結果及び考察}

\section{1. 接触面内微小すべり分布}

Fig.3に, 平面スタンプの表面形状が正方形の場合の, 接触面に発生した微小すへりの可視 化結果を示す. 図中のスケールは,すへり観測点上で発生した微小すべりの大きさを表して おり，接触域の大きさを表すものではない．更に，図中の線分は接触面内の観測点上に発生 した微小すべをを゙クトル表示したものであり，その観測点上ではスケールに対応する長さ の微小すへりが発生していることを意味している。そして, 図中の点で表示されている観測 点上では, 微小すべりが発生していないことになる.

Fig.3から, 平面スタンプの接触面には, 接線力の負荷によりすべり方向に対して接触域の 前方で微小すべりが発生することがわかる。また，この時接触域の後方には, 固着域が存在 していることがわかる。このすべり域は, 接線力の増加にともない接触域の後方へ進行して いく(Fig.3(c),(d),(e)).そして, 最終的に接触域全域がすべり域となったとき巨視的すべりが発 生する(Fig.3(f)). 


\section{2. 接触面内微小すべり発生領域と接線力係数の関係}

Fig.4に, 平面スタンプ接触の場合の, 接触面内微小すべりの発生している領域の接触面に占める 割合と接線力係数の関係を示す.ここで接触面内微小すべの発生している領域とは, 接触面内微 小すへりり分布図をもとに求めた值である.すなわち, 微小すべり分布図中, 線分で表示されている 箇所を微小すべりの発生している観測点とし、この観測点の数を全観測点の数で除した値である. この図から、いずれのスタンプの表面形状で あっても接線力係数が比較的小さい時には， 接触面にすべり域は存在しないが, 接線力係 数の増加にともない急激にすべり域が増加 する事がわる。しかし，接触面に占めるす へり域の割合は, スタンプの表面形状, 接線 力方向により異なることがわかる.この事か ら，垂直荷重が同一であってもス佂の表 面形状や接線力方向の違いにより摩擦係数 が巽なるのは, 接触面内微小すべりの分布状 態が異なることにより生じると考えられる。

5. まとめ

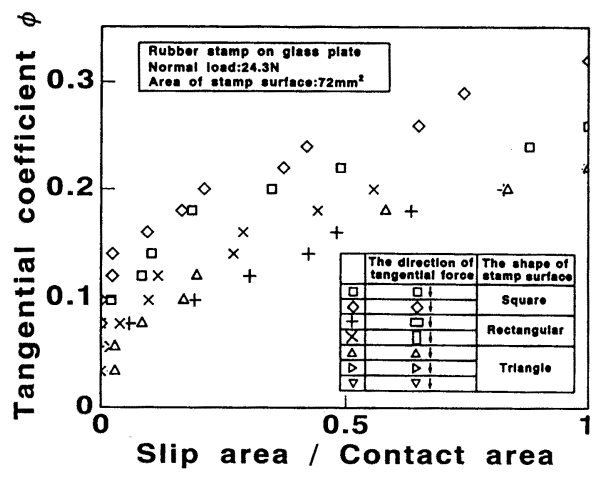

Fig.4: The relation of the tangential coefficient and the slip area.

・すべり出し過程の接触面を直接観察できる実験装置を開発し、画像処理技術を利用した 接触面に発生する微小すべりの可視化手法を開発し, 接触面内微小すべり分布の可視化 に成功した。

・ゴムとガラスの接触面を直接観察し, 接触面内微小すべりを可視化した結果, 微小すべ りの発生位置, 微小すべりの方向, 量, 及び接線力の増加にともなうすべり域の増加傾 向を明らかにすることができた。

・平面スタンプの接触の場合, 接線力の負荷により接線力作用方向に対して接触域前方に すべり域が発生し，接線力の增加にともないすへり域は後方へ進行していくことがわ かった。

・同じ垂直荷重, 接触面積でもスタンプの表面形状及び, 接線力方向の違いにより摩擦係 数が異なることを示し, それは接触面内微小すへりの分布状態の違いに関係しているこ とを示した。

\section{参考文献}

[1] J.S.Stevens, Phys.Rev, 8(1899), 49.

[2] R.D.Mindlin, J.Appl.Mech,71(1949), 259.

[3] D.Tabor, Proc.Roy.Soc, A251(1959), 378.

[4] 奥野, 日本造船学会誌, 第716号 (1989), 9 .

[5] 木村・高森・井上, 計测制御学会論文集, Vol.23, No2(1989), 1 .

[6] 大場・石原・猪岡, 流れの可視化, Vol.9, No33(1989), 77 . 